\title{
Hubungan Asi Eksklusifdengan Status Gizi Anak Usia 6- 24 Bulan Di Wilayah Kerja Puskesmas Benteng Kabupaten Indragiri Hilir Tahun 2019
}

\author{
Indah Dwi Aryani ${ }^{1}$, Syamsul Bahri Riva' ${ }^{2}$,Oktavia Dewi ${ }^{1}$, Nurlisis ${ }^{1}$, Ika Putri \\ Damayanti $^{2}$ \\ ${ }^{1}$ Program Studi Pascasarjana STIKes Hang Tuah Pekanbaru, Riau, Indonesia \\ ${ }^{2}$ Fakultas Kedokteran Universitas Abdurrab Pekanbaru \\ Email :indahdwiiaa31@gmail.com
}

\section{Abstract}

Nutritional status can be interpreted as a health status produced by a balance between nutritional needs and input. Nutritional status is largely determined by the availability of nutrients in sufficient quantities and in the right combination of time at the body cell level to develop and function normally. The purpose of this research is to know the relationship between exclusive breastfeeding and nutritional status of children aged 6-24 months in the working area of Benteng Puskesmas, Indragiri Hilir Regency in 2019. This research is an observational analytic quantitative with the type of analytical cross section study. This research was conducted from June to July 2019. Data analysis was carried out in stages including univariate analysis, bivariate analysis and multivariate analysis. The sampling procedure is done by Purposive Sampling with Quota Sampling with a sample size of 220 toddlers. The results of multivariate analysis, the most influential variable was exclusive breastfeeding $(P O R=5.263,95 \% C I=2.519-10.994)$.. Education $(P O R=4.146,95 \% C I=2.031-8.463)$. Family income $(P O R=2,190,95 \% C I=1,068-4,491) . T$ The conclusion in this study is that exclusive breastfeeding, education, and income are related to nutritional status. It is expected that mothers who have toddlers to better understand and improve information and knowledge about exclusive breastfeeding and also about nutrition and nutrition for children aged 6-24 months.

Keywords : breastfeeding, nutrional status, Benteng Fort Indragiri Hilir District Health Center in 201 


\begin{abstract}
Abstrak
Status gizi dapat diartikan sebagai status kesehatan yang dihasilkan oleh keseimbang anantara kebutuhan dan masukan zat gizi. Status gizi sangat ditentukan oleh ketersediaan zat gizi dalam jumlah cukup dan dalam kombinasi waktu yang tepat di tingkat sel tubuh agar berkembang dan berfungsi secara normal. Tujuan Penelitian ini di ketahuinya hubungan ASI eksklusif dengan status gizianakusia 6 - 24 bulan di Wilayah Kerja Puskesmas Benteng Kabupaten Indragiri Hilir tahun 2019. Penelitian ini bersifat Kuantitatif analitik observasional dengan jenis desai Studi Penampang Analitik. Penelitian ini dilaksanakan pada bulan Juni s/d Juli tahun 2019. Analisa data dilakukansecara bertahap meliputi analisis univariat, analisis bivariat dan analisis multivariat. Prosedur pengambilan sampel yang dilakukan secara Purposive Sampling dengan Quota Sampling dengan besar sampel 220 balita. Hasil analisis multivariat, variabel yang paling berpengaruh adalah ASI eksklusif ( $\mathrm{POR}=5,263$, CI 95\% = 2,519-10,994). Pendidikan(POR=4,146, CI 95\% = 2,031-8,463).Pendapatankelurga( $\mathrm{POR}=2,190, \mathrm{CI} 95 \%=1,068-4,491)$. Kesimpulan dalam penelitian ini adalah bahwa ASI eksklusif, pendidikan, dan pendapatan berhubungan dengan status gizi. Diharapkan kepada/ibu yang mempunya balita untuk lebih memahami dan meningkatkan informasi dan pengetahun tentang ASI eksklusif dan juga tentang asupan gizi dan nutrisi pada anakbalitausia 6-24 bulan.
\end{abstract}

\title{
Kata Kunci : ASI eksklusif, Status Gizi, Wilayah Kerja Puskesmas Benteng Indragiri Hilir,
} Tahun 2019.

\section{PENDAHULUAN}

Status gizi dapat diartikan sebagai status kesehatan yang dihasilkan oleh keseimbangan antara kebutuhan dan masukan zat gizi. Status gizi sangat ditentukan oleh ketersediaan zat gizi dalam jumlah cukup dan dalam kombinasi waktu yang tepat di tingkat sel tubuh agar berkembang dan berfungsi secara normal. Status gizi ditentukan oleh sepenuhnya zat gizi yang diperlukan tubuh dan faktor yang menentukan besarnya kebutuhan, penyerapan, dan penggunaan zat-zat tersebut. Masa bayi dimulai dari usia 0-12 bulan yang ditandai dengan pertumbuhan dan perubahan fisik yang cepat disertai dengan perubahan dalam kebutuhan zat gizi (Notoatmodjo, 2012).

Status gizi global adalah utama Penentu kesehatan dan kesejahteraan di antara anak-anak yang harus dipelajari dalam kaitannya dengan dimensi spasial dan temporal.Menurut UNICEF dan WHO (2016) gizi merupakan faktor utama kematian anak, penyakit dan kecacatan. Faktor yang berhubungan dengan gizi berkontribusi sekitar $45 \%$ dari kematian balita, diantaranya berat badan lahir rendah, kurang gizi, anak yang tidak diberi Air Susu Ibu (non ASI) dan lingkungan tidak sehat. Anak kurang gizi memiliki risiko kematian lebih tinggi akibat infeksi penyakit, seperti diare, pneumonia dan campak.

Terdapat dua faktor langsung yang dapat mempengaruhi status gizi individu, yaitu faktor makanan dan penyakit infeksi, dan keduanya saling mempengaruhi. Faktor penyebab langsung yang pertama adalah konsumsi makanan yang tidak memenuhi prinsip gizi seimbang. Faktor penyebab langsung adalah konsumsi makanan yang tidak memenuhi jumlah dan komposisi zat gizi yang memenuhi syarat gizi seimbang yaitu beragam, sesuai kebutuhan, bersih, dan aman, misalnya bayi tidak memperoleh ASI Eksklusif.Faktor penyebab langsung kedua adalah penyakit infeksi yang terkait dengan tingginya kejadian penyakit menular dan buruknya kesehatan lingkungan. Faktor lain yang juga berpengaruh yaitu ketersediaan pangan di keluarga, khususnya pangan untuk bayi 0 - 6 bulan (ASI Eksklusif) dan 6 - 24 bulan (MP-ASI), dan pangan yang bergizi seimbang khususnya bagi ibu hamil. Semuanya itu terkait pada kualitas pola asuh anak. Pola asuh, 
sanitasi lingkungan, akses pangan keluarga, dan pelayanan kesehatan, dipengaruhi oleh tingkat pendidikan, pendapatan, dan akses informasi terutama tentang gizi dan kesehatan. (Bapenas, 2013)

Usia 0-24 bulan (1.000 hari pertama kehidupan) merupakan masa pertumbuhan dan perkembangan yang pesat, sehingga sering diistilahkan sebagai periode emas sekaligus periode kritis. Periode emas dapat diwujudkan apabila pada masa ini bayi memperoleh asupan gizi yang sesuai untuk tumbuh kembang optimal. Sebaliknya apabila pada masa ini bayi tidak memeperoleh asupan makanan sesuai kebutuhan gizinya, maka periode emas dapat berubah menjadi periode kritis yang akan menganggu tumbuh kembang, baik pada saaat ini maupun masa selanjutnya (Depkes, 2010).

ASI eksklusif pada penelitian ini terdiri dari ASI eksklusif frekuensi menyusu dan lama menyusu pada anak 6-24 bulan. Pemberian makanan yang tepat dan optimal sangat penting untuk pertumbuhan dan perkembangan anak. Menurut Global Strategy For Infant And Young Child Feeding, WHO/UNICEF tahun 2016 adalah menyususi bayi sesegera mungkin setelah lahir, pemberian ASI secara eksklusif sejak lahir sampai bayi berusia 6 bulan, memberikanan makanan pendamping air susu ibu (MP-ASI) sejak bayi berusia 6-24 bulan, dan meneruskan pemberian ASI sampai anak berusia 24 bulan atau lebih.

Hasil penelitian di India menyatakan bahwa penderita kekurangan gizi pada anak dibawah lima tahun adalah 41,2\%. Kekurangan gizi sangat berkaitan dengan umur, status sosial, ekonomi, pendidikan ibu, praktek imunisasi dan makanan. Inisiasi menyusu dini, dan tidak menyusu secara eksklusif dapat menimbulkan resiko yang signifikan terhadap kasuskekurangan gizi (Luthra ea al, 2010).

Menurut Data dari Riskesdas tahun 2018 tentang gizi balita di indonesia adalah 17,7 \%,terdiri dari dari balita mengalami gizi buruk sebesar 3,9\% dan balita mengalam gizi kurang 13,8\% (Kemenkes, RI 2018). Menurut laporan dalam buku profil kesehatan Provinsi Riau tahun 2016 Prevalensi balita mengalami gizi buruk 1,1 \% dan balita mengalami gizi kurang 7,9\%. Dan pada tahun 2016 terdapat Kabupaten Indragiri Hilir merupakan prevalensi gizi kurang yang tertinggi yakni sebesar 10,4 \% diikuti oleh Kabupaten Kampar 10\% dan Kabupaten Indragiri Hulu 9,8\%.(Dinkes Provinsi Riau, 2017)

Menurut laporan Dinas Kesehatan Kabupaten Indragiri Hilir prevalensi gizi kurangtahun 2018 terdapat $0,83 \%$, dari seluruh jumlah balita yang ditimbang (Dinkes Kabupaten Indragiri Hilir, 2018). Data dari puskesmas Benteng pada tahun 2017 dari 450 balita yang ditimbang terdapat 38 orang 7,3\% balita dengan status gizi kurang. Dan Pada tahun 2018 dari 588 balita yang ditimbang dengan status gizi kurang 45 orang7,6\% dan dapat dilihat terjadi peningkatan balita dengan gizi kurang.(Profil Puskesmas Benteng, 2018)

Data dari Profil Kesehatan Indonesia tahun 2017 menunjukkan cakupan bayi mendapat ASI eksklusif sebesar 61,33\%. Presentasepemberian ASI eksklusif tertinggi menurutt provinsi terdapat di provinsi Nusa Tenggara Barat (87,35\%), sedangkan persentase terendah terdapat pada Papua (15,32\%). (Kemenkes RI, 2017). Di Provinsi Riau cakupan pemberian ASI eksklusif tahun 2016 sebesar 56,2\%, dan pada tahun 2017 sebesar 33,0\%. Secara nasional rata-rata cakupan ASI eksklusif sebesar 54,3\%, sekitar 45,7\% bayi Indonesia belum terpenuhi haknya untuk memperoleh ASI eksklusif (INFODATIN, 2014).

Data dari Dinas Kesehatan Kabupaten Indragiri Hilir pada tahun 2017 menunjukan cakupanpemberian ASI pada bayi 0-6 bulan13,1\%,dan mengalami peningkatan pada tahun 2018 sebesar 17,1\%.Berdasarkan data Profil Puskesmas Bentengcakupan pemberian ASI eksklusif pada tahun 2018 hanya mencapai target sebesar 47\%. (Profil Puskesmas Benteng, 2018).Target capaian cakupan pemberian ASI eksklusif pada bayi 0-6 bulan minimal 80\% sampai saat ini masih sulit dicapai. Pemberian ASI eksklusif pada bayi usia 0 - 6 bulan menjadi salah satu upaya dalam rangka 
kesehatan ibu dan bayi, sehingga pemberian ASI juga menjadi indikator dari penurunan angka kematian ibu dan bayi (Sri Damayanti, 2015).

Penelitian Dwi (2018), tentang hubungan pemberian ASI Eksklusif dengan status gizi balita usia 6-24 bulan menunjukkan adanya kecendurungan bahwa ibu yang memberikan ASI Eksklusif memiliki balita status gizi lebih baik dari pada ibu yang tidak memberikan ASI Eksklusif. Dalam Penelitian susanti (2012), di makassar mengungkapkan lama menyusi dalam sehari juga berhubungan dengan gizi buruk. Ini berarti, balita yang mendapatkan ASI dengan lam Pemberian rat-rata $<10$ menit tiap satu kali disusui memiliki resiko menderita gizi buruk sebesar 3,75 kali lebih besar dibandingkan dengan balita yang disusui selam $\geq 10$ menit tiap 1 kali. Dan jika pemberian ASI dapat terlaksana dengan baik, akan dapat menimbulkan dampak positif terhadap pertumbuhan dan perkembangan anak diusia balita.

Dari survei awal yang telah peneliti lakukan diwilayah kerja puskesmas Benteng Kabupaten Indragiri Hilir, didapatkan dari 20 orang responden 12 anak usia 6-24 bulan tidak ASI eksklusif dan 5 anak yang mengalami gizi kurang, dan 8 anak usia 6-24 bulan mendapatkan ASI eksklusif dengan status gizi baik.Berdasarkan latar belakang diatas peneliti ingin melakukan penelitian lebih lanjut tentang hubungan riwayat ASI dengan status gizi anak 6-24 bulan diwilayah kerja puskesmas Benteng Kabupaten Indragiri Hilir 2019.

\section{METODE PENELITIAN}

Penelitian ini adalah penelitian kuantitatif dengan menggunakan observasional analitik. Tujuan penelitian ini untuk mengetahui Diketahuinya hubungan ASI eksklusif dengan status gizi anak usia 6-24 bulan di wilayah kerja Puskesmas Benteng Kabupaten Indragiri Hilir.Desain penelitian ini menggunakan pendekatan cross sectional. Populasi pada penelitian ini berjumlah 899 balita. Sampel adalah sebagian balita anak usia 6-24 bulan.Penelitian ini menggunakan metode purposive sampling dengan quota sampling. Variabel Independen adalahASI eksklusif, Frekuensi menyusu, Lama menyusu, pola asuh makan, pendidikan ibu, pekerjaan ibu, pendapatan ibu. Variabel dependen adalah status gizi anak usia anak usia 6-24 bulan Data yang dikumpulkan adalah data primer dari semua variabel independen dengan memberikan kuesioner pada responden. Pengolahan data menggunakan editing, coding, scoring, dan cleaning. Analisis bivariate dilakukan dengan uji Chi-square dan untuk analisis Multivariat dilakukan dengan uji Regresi logistik ganda. Penelitian ini sudah melalui kaji etik penelitian dengan sudah dikeluarkannya surat etik penelitian.

\section{HASIL DAN PEMBAHASAN}

\section{Analisis Univariat}

Hasil analisis univariat pada variabel dependen yaitu status gizi anak 6-24 bulan diwilayah kerja puskesmasBenteng Kabupaten Indragiri Hilir 2019 menunjukkan bahwa 23,6\%

anak balita mengalami gizi kurang. Analisis univariat pada variabel independen menunjukkan bahwa anak balita usia 6-24 bulan dengan ASI tidak eksklusif sebesar 43,2\%, anak balita dengan frekuensi menyusu kurang sebesar $37,3 \%$, anak balita dengan lama menyusunya kurang sebesar $25,9 \%$, anak balita dengan pola asuh makan yang kurang sebesar $57,7 \%$, anak balita dengan pendidikan ibunya rendah sebesar 30\%, anak balita yang ibunya tidak bekerja sebesar 56,8\% dan anak balita yang pendapatan keluarganya kurang sebesar $47,7 \%$.

\section{Analisi Bivariat}

Hasil analisi menunjukan 7 variabel Independen ada 5 variabel independen yang behubungan secara signifikan $(\mathrm{P}<0,05)$ dengan status gizi anak yaitu : ASI Eksklusif $(\mathrm{CI} 95 \%$ : $\mathrm{OR}=2,649-$ 10,549). frekuensi menyusu (CI 95\%: OR=1,306 - 4,644). Pendidikan ibu (CI 95\%: OR=2,31,3 8,618). Pekerjaan ibu (CI 95\%: OR=1,276 - 5,005). Pendapatan keluarga (CI 95\%: OR=1,350 4,934). 
Tabel 1. Hubungan Variabel Independen Dengan Status Gizi Di Wilayah Kerja Puskesmas Benteng Kabupaten Indragiri Hilir Tahun2019

\begin{tabular}{|c|c|c|c|c|c|}
\hline & \multicolumn{3}{|c|}{ Status Gizi } & \multirow[b]{2}{*}{ P Value } & \multirow{4}{*}{$\begin{array}{l}\text { POR (95\% } \\
\text { CI) }\end{array}$} \\
\hline & Gizi & Gizi Baik & Total & & \\
\hline \multirow{2}{*}{$\begin{array}{r}\text { Status Gizi } \\
\text { Variabel }\end{array}$} & Kurang & & & & \\
\hline & $\mathrm{n}(\%)$ & $\mathrm{n}(\%)$ & $\mathrm{n}(\%)$ & & \\
\hline \multirow{3}{*}{$\begin{array}{l}\text { ASI Eksklusif } \\
\text { Tidak Eksklusif } \\
\text { Ekslusif }\end{array}$} & & & & & $5,2 \quad(2,649 \quad$ \\
\hline & $38(40,0)$ & $57(60,0)$ & $95100,0)$ & 0,001 & $10,549)$ \\
\hline & $14(11,2)$ & $111(88,8)$ & $125(100,0)$ & & \\
\hline $\begin{array}{l}\text { Kurang ( }<8 \text { Kali }) \\
\text { Baik }(\geq 8 \text { kali })\end{array}$ & $\begin{array}{l}28(34,1) \\
24(17,4)\end{array}$ & $\begin{array}{l}54(65,9) \\
114(82,6)\end{array}$ & $\begin{array}{l}82(100,0) \\
138(100,0)\end{array}$ & 0,008 & $\begin{array}{c}2,4(1,306- \\
4,644)\end{array}$ \\
\hline $\begin{array}{l}\text { Kurang ( }<10 \text { menit) } \\
\text { Baik ( } \geq 10 \text { menit })\end{array}$ & $\begin{array}{l}14(24,6) \\
38(23,3)\end{array}$ & $\begin{array}{l}43(53,4) \\
125(76,7)\end{array}$ & $\begin{array}{l}57(100,0) \\
163(100,0)\end{array}$ & 0,992 & - \\
\hline $\begin{array}{l}\text { Kurang } \\
\text { Baik }\end{array}$ & $\begin{array}{c}31(24,4) \\
21(22,6 \%)\end{array}$ & $\begin{array}{l}96(75,6) \\
72(77,4) \\
\end{array}$ & $\begin{array}{c}1 \\
27(100,0) \\
93(100,0)\end{array}$ & & - \\
\hline $\begin{array}{l}\text { Pendidikan ibu } \\
\text { Rendah } \\
\text { Tinggi }\end{array}$ & $\begin{array}{l}29(43,9) \\
23(14,9) \\
\end{array}$ & $\begin{array}{c}37(56,1) \\
131(85,1) \\
\end{array}$ & $\begin{array}{c}66(100,0) \\
154(100,0) \\
\end{array}$ & 0,001 & $\begin{array}{c}4,4(2,31,3- \\
8,618)\end{array}$ \\
\hline Bekerja & $\begin{array}{l}38(30,4 \%) \\
14 \\
(14,7 \%) \\
\end{array}$ & $\begin{array}{l}87(68,6) \\
81(85,3 \%)\end{array}$ & $\begin{array}{l}125(100,0) \\
195(100,0)\end{array}$ & & $\begin{array}{l}2,5(1,276- \\
5,005)\end{array}$ \\
\hline $\begin{array}{l}\text { Pendapatan Keluarga } \\
\text { Kurang (<Rp 2,750,618) } \\
\text { Cukup (>Rp 2,750,618) }\end{array}$ & $\begin{array}{l}34(31,4) \\
18(15,7) \\
\end{array}$ & $\begin{array}{l}71(67,6) \\
97(84,3)\end{array}$ & $\begin{array}{l}105(100,0) \\
115(100,0) \\
\end{array}$ & 0,006 & $\begin{array}{l}2,8(1,350- \\
4,934)\end{array}$ \\
\hline
\end{tabular}

Tabel 2. Analisis Multivariat (Pemodelan Terakhir)

\begin{tabular}{llcccc}
\hline No & Variabel & $\boldsymbol{P}$ Value & POR & \multicolumn{2}{c}{ 95\% CI } \\
\hline & & & Lower & Upper \\
\hline 1. & ASI eksklusif & 0,001 & 5,263 & 2,519 & 10,994 \\
\hline 2. & Pendidikan ibu & 0,001 & 4,146 & 2,031 & 8,463 \\
\hline 3. & Pendapatan keluarga & 0,032 & 2,190 & 1,068 & 4,491 \\
\hline Omnimbus Test $=\mathbf{0 , 0 0 1}$ & & nagelkerke $\boldsymbol{R}$ Square $=\mathbf{0 , 2 9 1}$
\end{tabular}




\section{Analisis Multivariat}

Hasil analisis multivariat dapat disimpulkan bahwa variabel independen yang dominan adalah ASI eksklusif, Pendidikan Ibu, dan Pendapatan Keluarga.

\section{PEMBAHASAN}

\section{Hubungan ASI eksklusif dengan Status Gizi Anak Usia 6-24 Bulan}

Pada penelitian ini, hasil analisis multivariat menunjukkan variabel ASI eksklusif secara statistik berhubungan dengan status gizi balita dengan nilai OR 5,286 kali (CI 95\%: OR=2,649 - 10,549). artinya anak yang tidak mendapatkan ASI Eksklusif memiliki peluang 5,2 kali lebih besar mengalami status gizi kurang dibandingkan dengan anak yang mendapatkan ASI eksklusif.

Menurut penelitian yang dilakukan oleh Kurnia (2013), tentang hubungan pemberian ASI Eksklusif dengan status gizi balita usia 6-24 bulan di Kampung Kajanan, Buleleng, menunjukkan adanya kecendurungan bahwa ibu yang memberikan ASI Eksklusif memiliki balita status gizi lebih baik dari pada ibu yang tidak memberikan ASI Eksklusif.

Hal ini terlihat ibu yang tidak memberikan ASI Eksklusif sebanyak 9\% memiliki balita diatas garis merah dan 1,3\% memiliki status gizi dibawah garis merah. Sedangkan pada ibu yang memberikan ASI Eksklusif sebanyak,4\% memiliki balita dengan status gizi diatas garis merah dan 15,4\% memiliki balita dengan status gizi dibawah garis merah. Oleh karena itu direkomendasikan agar tidak mengalami satus gizi kurang, pada anak usia 6-24 bulan maka diharapkan pemberian ASI eksklusif selama 6 bulan tanpa pemberian makanan atau minuman selain ASI dan pada usia 6-24 bulan diberikan MP-ASI yaitu makanan atau minuman yang mengandung gizi, diberikan guna memenuhi gizi selain ASI.

\section{Hubungan Pendidikan Ibu Dengan Status Gizi Anak Usia 6-24 Bulan}

Pada penelitian ini, hasil analisis multivariat menunjukkan variabel Pendidikan Ibu secara statistik berhubungan dengan status gizi balita dengan nilai $\mathrm{POR}=4,146, \mathrm{CI} 95 \%=2,031-8,463)$. Artinya responden yang memilikipendidikan rendah memiliki peluang 4,1 kali lebih besar mengalami status gizi balita dibandingkan dengan responden yang memiliki pendidikan tinggi.Pendidikan merupakan suatu usaha sadar seseorang untuk mengembangkan kepribadian dan kemampuan didalam dan diluar sekolah. Dikatakan pula bahwa tingkat pendidikan rata-rata masih rendah, khususnya kalanagan wanita merupakan salah satu masalah pokok yang menjadi pengaruh terhadap masalah kesehatan. Makin tinggi tingkat pendidikan seseorang, makin mudah mendapatkan dan menerima informasi pengetahuan mengenai penyediaan makanan yang baik. (Andriyani \& Wirjatmmadi, 2014).

Menurut penelitian Nur Azikin, (2016) hasil penelitian ini menunjukan hasil yang signifikan dengan $\mathrm{p}=0,001$. Artinya terdapat peran pendidikan ibu terhadap status gizi balita. Hasil serupa juga dilakukan oleh Zulhijah dkk di Kabupaten Tenmuna Sulawesi dengan hasil $\mathrm{p}=0,000$ selain itu Rona dkk juga mendapatkan dan teori yang ada menunjukan bahwa pendidikan berhubungan dengan status gizi karena pendidikan yang tinggi, kemungkinan pendapatan akan meningkat.. Oleh karena itu agar tidak terjadi status gizi kurang pada anak balita usia 6-24 bulan, direkomndasikan kepada ibu yang berpendidikan kurang dapat meningkatkan pengetahuan dan kemampuan ibu dalam memberikan dan menyediakan pangan dalam jumlah dan jenis yang cukup.

\section{Hubungan Pendapatan Keluarga dengan status gizi anak usia 6-24 bulan}

Pada penelitian ini, hasil analisis multivariat menunjukkan variabel pendapatan keluarga secara statistik berhubungan dengan status gizi balitadengan nilaiPOR=2,190, CI 95\% = 1,068-4,491). 
Artinya responden yang pendapatan keluarga kurang memiliki peluang 2,1kali lebih besar mengalami status gizi dibandingkan dengan pendapatan keluarga cukup.Menurut hasil penelitian Mulazimah menunjukan bahwa pendapatan keluarga mempunyai hubungan yang bermakna secara statistik dengan status gizi balita. Berdasarkan hasil penelitian menunjukan pendapatan keluarga mempunya keluarga mempunyai hubungan yang signifikan terhadap status gizi balita $\mathrm{p}=$ 0,014 (0,05). Pada keluarga mampu biasanya akan mengeluarkan sebagian besar pendapatan tambahan untuk membeli makanan pokok. Sedangkan pada keluarga mampu, semakin tinggi pendapatan semakin bertambah besar persentase pertambahan pengeluaran untuk buah-buahan, sayur-sayuran dan jenis makanan lainya. Faktor sosial ekonomi berhubungan dengan kemampuan keluarga untuk mencukupi kebutuhan zat gizi. Oleh karena itu agar tidak terjadi status gizi kurang pada anak balita usia 6-24 bulan direkomndasikan agar orang tua dapat meningkatkan pendapatan mereka.

\section{PENUTUP}

\section{Kesimpulan}

Berdasarkan uraian pada bab hasil penelitian dan bab pembahasan maka dengan ini penelitian mengambil keputusan :

1. Proporsi anak balita usia $6-24$ bulan yang status gizi kurang yang berada diwilayah kerja Puskesmas Benteng sebanyak 52 orang yaitu $(23,6 \%)$ dari 220 orang anak balita.

2. Anak balita berusia 6- 24 bulan yang tidakmendapatkan ASI Eksklusif memiliki peluang 5,2 kali lebih besar mengalami status gizi kurang dibandingkan dengan anak yang mendapatkan ASI eksklusif POR=5,263.

3. Ibu yang memiliki pendidikan rendah lebih berisiko 4,1 kali terhadap status gizi balita dibandingkan responden yang memiliki pendidikan tinggi $\mathrm{POR}=4,146$.

4. Pendapatan keluarga yang kurang lebih berisiko 2,1 kali terhadap status gizi balita dibandingkan responden dengan pendapatan keluarga cukupPOR=2,190.

5. Variabel yang tidak memiliki hubungan sebab akibat dengan status gizi adalah variabel frekuensi menyusu, lama menyusu, Pola Asuh dan Pekerjaan ibu.

\section{Saran}

\section{Saran Dalam Signifikansi Sosial}

1. Diharapkan kepada Pihak puskesmas, tenaga kesehatan, kader dan stakeholder dapat kerjasama untuk meningkatkan pemberian ASI eksklusif pada balita usia 6 - 24 bulan, untuk meningkatkan status gizi di wilayah Kerja Puskesmas Benteng.

2. Diharapkan kepada tenaga kesehatan dapat memberikan penyuluhan maupun konseling kepada ibu hamil dan ibu yg mempunyai bayi balita tentang cara pemberian makanan bayi serta pentingnya ASI eksklusif yang dilakukan secara berkala dan berkelanjutan

3. Diharapkan kepada tenaga kesehatan untuk membentuk kelas ibu hamil dan ibu yg mempunyai bayi balita sebgai lahan diskusi kesehatan khususnya untuk makanan bayi

4. Diharapkan kepada ibu untuk perlu peningkatan kesadaran tentang pentingnya pemberian ASI eksklusif bagi bayi dan balita untuk menunjang pertumbuhan

\section{Saran Dalam Signifikansi Ilmiah}

Bagis peneliti selanjutnya Sebagai bahan masukan untuk referensi penelitian selanjutnya mampu mengembangkan penelitian dengan menggunakan variabel yang lain terkait dengan pemberian ASI eksklusif atau variabel lain yang belum diteliti seperti umur, dukungan keluarga, dan motivasi.

\section{DAFTAR PUSTAKA}

Andriani, R., Wismaningsih, E. R., \& Indrasari, O. R. (2015). Hubungan Pemberian Asi Eksklusif 
Dengan Kejadian Status Gizi Kurang Pada Balita Umur 1 - 5 Tahun Correlation BetweenExclusiveBreastfeedingProvision With Toddler'S Malnutrition Status Age 1 - 5 Years Old. 44-47.

Bappenas. (2013). Rencana Aksi Nasional Pangan dan Gizi 2011-2015. Retrieved Maret 13, 2019 from www.bappenas.go.id

Depkes, RI. (2010). Buku pedoman startegi KIE Keluarga Sadar Gizi (Kadarzi)Jakarta : Departemen Kesehatan RI.

Dinkes. Provinsi Riau. (2017). Profil Dinkes Provinsi Riau 2017. Pekanbaru: Dinkes Provinsi Riau

Dinkes. Kabupaten indargiri hilir. (2012). Profil Dinkes Kabupaten indargiri hilir 2018. Pekanbaru: Dinkes Kabupaten indargiri hilir

INFODATIN, 2014. Situasi dan analisis ASIeksklusif. Kemenkes RI. Jakarta

Kemenkes RI, (2017) Penilaian Status Gizi. Jakarta :Kementrian Kesehatan Republik Indonesia. Notoatmodjo S. (2012). Ilmu Kesehatan Masyarakat Prinsip - Prinsip Dasar Jakarta: Rineka Cipta Puskesmas, Benteng. (2018). Profil Puskesmas Benteng 2018. Benteng : Puskesmas Bentang Sri, D., Nurdianti dan Kamrin. (2015). Pemberian ASI Eksklusif Pada Bayidi Wilayah Kerja PuskesmasKemaraya Kota Kendari. JurnalKesehatan Masyarakat. Vol.1,

Supariasa, 2012. penilaian Status Gizi. Jakarta : EGC

WHO.and UNICEF. (2016). Regional Report on Nutrition Security in Asean. Volume 2.

Mulazaimah, (2015). Hubungan Pendapatan Keluarga Dengan Status Gizi Balita Desa Ngadiluwih Kecamatan Ngadiluwih Kabupaten Kediri. Skripsi. Akbid Kebidanan PGRI Kediri. Kediri.

Jannah, M dan Maesaroh, S. 2014. Hubungan antara Tingkat Pendidikan Ibu dengan Status GiziBalita di Posyandu Bangunsari Semin Gunung Kidul. Media Gizi Indonesia. 10 (1) : 8490.

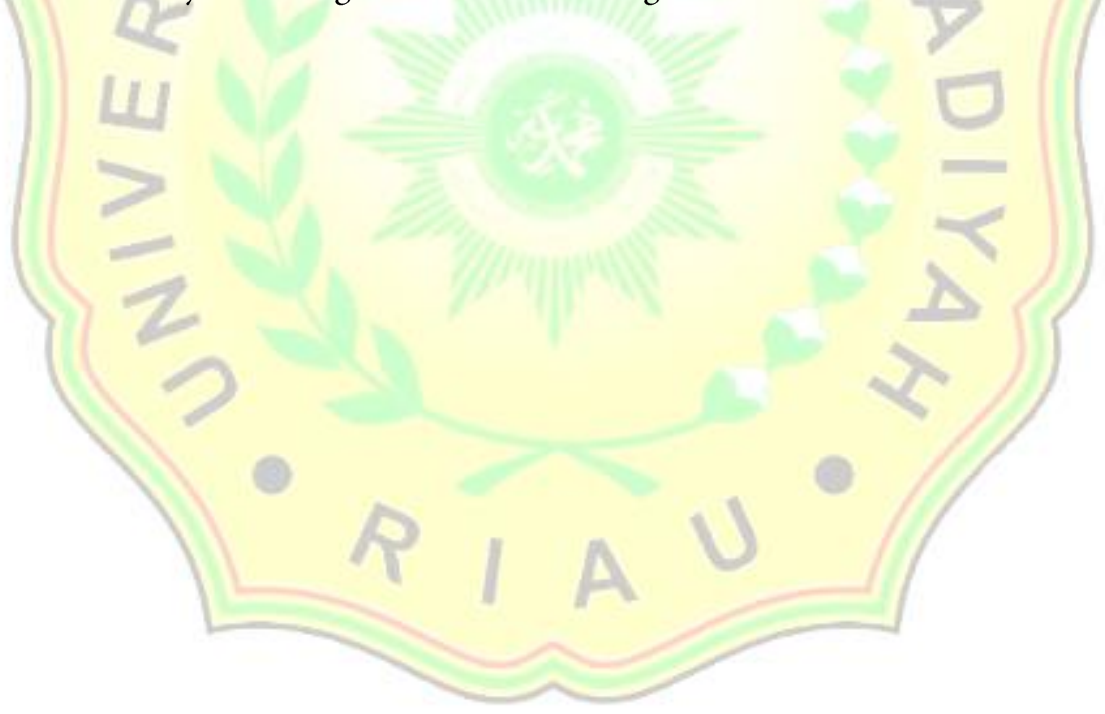

